UDC 811.111'373

https://doi.org/10.18485/bells.2018.10.3

\author{
Luna Filipović* \\ University of East Anglia \\ Norwich, UK
}

\title{
LANGUAGE CONTRASTS IN TRANSLATION: COGNITIVE AND PRACTICAL CONSEQUENCES ${ }^{1}$
}

\begin{abstract}
Can language differences bring about different conceptualisations of events? We shall see in this paper that they can, in the context of translation and also in some other contexts of language use, such as memory and judgment. The focus here is primarily on translation and its relationship with other research areas such as contrastive and cognitive linguistics. I illustrate how all these areas can be mutually informative and benefit from a closer interaction. The theoretical background for the analysis is given within the framework of Applied Language Typology, which is a novel platform for investigation of language contrasts in different practical contexts of multilingual use, such as interpreting, translating, language learning and teaching or legal communication such as police interviews and evidence-gathering. Two cognitive domains, motion and causation and the means to lexicalise them in different languages are discussed, including contrasting features at the morphological, syntactic and semantic level. I conclude that a holistic approach to language contrasts, which involves use of different empirical approaches that probe for their cognitive and practical consequences, is the way forward for contrastive applied language research.
\end{abstract}

Key words: causation, deixis, intentionality, motion, translation

E-mail address: 1.filipovic@uea.ac.uk

1 To Professor Ranko Bugarski, my first mentor, with gratitude and affection. 


\section{Introduction}

Languages differ in many ways and many language contrasts have direct consequences for a variety of language-driven activities. For instance, in the context of translation, the presence of a lexical or grammatical category in one language and their absence in another can lead to a variety of issues, such as how to convey the exact original meaning in the translated text without making the narrative sound awkward, or how to keep the form without losing the entirety or parts of the original meaning. In some cases the choices we make in translation can affect not only the intended meaning or style but can also have important effects on concrete outcomes of events in real life that go beyond communication per se. It is these kinds of effects that we highlight in this paper.

Our focus is on cognitive and practical consequences of typological differences between languages that arise in the context of translation. We are particularly interested in conceptual differences induced by linguistic differences between the original (source) language and the language of the translation (target) as well as language-specific effects on how the described events are remembered depending on the language of their description.

For the purpose of the current discussion, I first introduce the relevant theoretical framework, applied language typology (Filipović 2017a, 2017b), within which emphasis is put on those typological contrasts between languages that result in significant practical problems and require difficult decisions to be made in order to overcome them in cross-linguistic communication (Section 2). The applied language typology approach helps us identify the key contrasts, document their effects empirically and raise awareness about their impact and importance in communication and language education. The examples discussed are taken from two different linguistic and cognitive domains in order to illustrate the relevance of an applied typology approach at different levels of analysis. I discuss the morphosyntactic and semantic contrasts in the lexicalisation and translation of deictic motion in English, Serbian and Spanish (Section 3) and expression of intentional vs. unintentional causation in these three languages (Section 4). I also highlight some important effects of these language contrasts beyond the conflict in translation and illustrate their impact on witness memory and judgment, which may be impacted differently depending on whether they are guided by the language of the original statement or that 
Luna Filipović: Language Contrasts in Translation

of the translation. Section 5 offers conclusions and recommendations for further research.

\section{Language contrasts from an applied language typology perspective}

\subsection{Contrastive and cognitive approaches: A brief overview}

The study of language contrasts has been taking place for many years within different theoretical and practical frameworks. This paper explores the possibility of a unified approach to the study of language contrasts that pulls together key insights from different sources and that is both theoretically sound and practically useful. In what follows I provide a brief introduction to the background for the current analysis, which originally combines typological descriptions of language contrasts with knowledge about how language is represented in the mind and the effects that the contrasting linguistic framing of experience may have on how experience is conceptualised. This innovative framework, applied language typology, brings to the fore the crucial importance of empirical testing of typological predictions in concrete contexts of use with the purpose of identifying the effects of typological similarities and differences on the way speakers think, remember and learn.

The study of language contrasts was of central concern within the contrastive linguistics paradigm (at least since Lado 1957), guided by a contrastive analysis approach, which was used to describe categories and rules in two different languages and highlight the contrasts between them. It was soon criticised due to both overprediction and underprediction regarding when and where difficulties in language learning may occur (see Odlin 1989: 17; see also James 1990 for a comprehensive account of contrastive linguistics). For instance, certain pedagogical assumptions were made, such as that if similarities existed between two languages those features would be easier to master in L2 acquisition, and vice versa, differences meant difficulties in L2 acquisition. It was demonstrated by empirical testing of such assumptions that the picture was not that simple. Sometimes similarities did not lead to easy or fast acquisition because learners would avoid the structures that they considered L1-specific even though the same or similar ones existed in L2 (which is captured by the notion of 
psychotypology (Kellerman 1983)). Similarly, some features that are very different in L2 from those in L1 tend to be acquired very early and very fast if they are indispensable for making oneself understood in L2 (see Filipović and Hawkins 2013). Yet, many valuable recommendations coming from this tradition are still valid today. For example, Eric Hawkins (1984) proposed raising language awareness in the classroom, which involves incorporating simple contrastive analysis to serve as interface between mother tongue and foreign language study. Experimental teaching that raises foreign language learners' awareness of contrasts between the mother tongue and the foreign language was shown to facilitate the learning of difficult foreign language structures (Kupferberg and Olshtain 1996).

Importantly, focusing on systemic differences just between two languages and not including information about how those systems are actually used appeared to be problematic for the contrastive approach. The advent of generative linguistics did not help either because, in addition to focusing almost only on English for many years, it also brought an exclusive focus on what may be universal in languages, which in practice ended up being an attempt to impose categories from English in the analysis of other languages. Thankfully, the tide shifted again and the work on language typology that comprised both language contrasts and language universals started to emerge (Greenberg 1964, 1966; Hawkins 1983, 1986). Cognitive approaches to the study of language, such as cognitive linguistics (see Ungerer and Schmidt 1996 for an overview), also supported the idea that the study of language contrasts is of key importance for linguistic theory and our knowledge about the relationship between language and the mind. In general, the cognitive turn across disciplines has incited renewed interest in language contrasts and their cognitive consequences in different context of language use.

Precursors of these progressive research ideas in both contrastive and cognitive camps can be traced to Bugarski's impressive and versatile opus. As early as in his PhD study in 1969 of a subsystem of prepositions in English, Bugarski (1996 [1969]) showed how differences in linguistic framing can lead to differences in conceptual framing. This work was an early account of how language relates to conceptualisation of domains of human experience, such as spatial or temporal. Cognitive linguistics and other usage-based frameworks have been exploring these domains extensively, as illustrated in recent studies (see e.g. Filipović and Jaszczolt 2012a, 2012b; IbarretxeAntuñano 2017). Furthermore, Bugarski (1991) proposed a reformed 
definition of the contrastive analysis approach whereby contrastive linguistics would be defined as "the systematic study of similarities and differences in the structure and use of two or more language varieties, carried out for theoretical or practical purposes". This reconceptualisation of contrastive linguistics actually cures all its past ailments, namely the narrow approach of contrasting just two systems. Crucially, as proposed by Bugarski, contrastive studies should include language in use rather than lists of features in vacuum, as it were, stripped of any context. Thus, practical purposes are put on an equal standing with theoretical goals, where they should be, and it is this kind of purposes that the current paper is focused on.

Another general point is worth making here. Contrastive linguistics has reclaimed its practical significance with the rising interest in Interlanguage studies. The traditional approach was to compare the learner's mother tongue (L1) with the language (L2) to be learnt. Current approaches within Interlanguage research contrast the learner's version of the L2 with the standard version of that L2 and discuss the influences of many factors on the learners' L2s (including L1 transfer in particular; see Odlin 1989). More recently, contrastive linguistics practices have been adopted by psycholinguistics, which previously addressed prevalently monolingual language processing, working mainly on English. The value of bilingual and multilingual data for the study of language processing in general, and the relationship between language and cognition is becoming increasingly documented (e.g. Athanasopoulos 2016; Filipović 2011, 2013; Lai et al. 2014; Pavlenko, 2014). It is essential to study language contrasts in a variety of contexts, such as interpreting, translating, language learning and teaching, since language contrasts may manifest themselves differently. For example, what is problematic in interpreting (e.g. Japanese word order translated into English) may not be difficult in acquisition (e.g. Japanese learners of English master the English word order early; see Filipović and Hawkins 2013 for details).

Translation is one of the fundamental areas of language use that provides examples of language contrasts and their effects. The cognitive turn in translation studies has contributed to the treatment of translation data as significant for our understanding of bilingual language use and bilingualism more generally (see House 2013; see also Halverson 2014 for a succinct and insightful overview). Furthermore, translation is a prolific testing ground for predictions arising within the field of cognitive linguistics, as has been demonstrated by numerous studies in Rojo and 
Ibarretxe-Antuñano 2013 (see also Rojo and Cifuentes-Ferez 2017; Ibarretxe-Antuñano and Filipović 2013; Filipović and Ibarretxe-Antuñano 2015). The results of these studies provided new knowledge into how translation can impact a number of cognitive functions, such as witness memory and judgment. Use of experimental and corpus approaches in translation research has offered novel ways in which to seek empirical confirmation for effects of differences between languages, document their manifestations and assess their relevance for different language-driven activities, such as interpreting, translating, language learning, language teaching, witness interviewing, political or business negotiating, and possibly others.

Overall, translation data are a rich source of information that can be used for testing of numerous hypotheses related to both linguistic theory and language use in bilingual and multilingual communication. This paper is a contribution in this vein.

\subsection{Applying language typology}

The backdrop for the current discussion is the applied language typology approach, a framework first proposed by Filipović (2008) and developed in Filipović (2017a, 2017b). Applied Language Typology is grounded in the cognitive linguistic belief that there is a close relationship between how objects and events are described in language and how they are conceptualised, and it contrasts languages on a large typological scale in order to probe for effects of different linguistic typological framing of categories and events. Apart from the original combination of multiple perspectives and sources of insights, the novelty is reflected in the research goals that lie in the essence of this framework, namely the empirical documentation of effects that typological similarities and differences have in different contexts of language use, e.g. translation, second language acquisition, witness memory, etc. This approach helps us identify more precisely when and how various factors will facilitate or impede successful language use in different contexts. These features of languages relevant to professional practice may vary from context to context (e.g. as mentioned in the previous section, what is easy in language learning may still be difficult in translation and vice versa; see Filipović and Hawkins 2013 for details), but all applications can benefit from a clear and general classification scheme that identifies the precise points of contrast between 
languages (see further below). This applied typology approach aims to add the crucial empirical feedback element on the effects of the typological language contrasts for different language-driven activities and in different professional contexts (e.g. medical, legal, educational), and for a variety of languages from different typological groups.

Filipović (2017a, 2017b) identified certain general criteria that we can use in order to detect those language contrasts that can potentially result in practical difficulty, regardless of the particular area of grammar or lexicon in which they originate. Not all differences between two languages will necessarily lead to miscommunication and mistranslation or indeed to facilitated communication and translation. The following three general types of contrasts between languages appear to be centrally important for a number of applied domains:

a) the presence vs. absence of a category (lexical or grammatical) in two or more contrasted languages (e.g. evidential marking exists in Turkish and Japanese, but not in English; affective dative construction is found in Spanish and Serbian, but not in English; see sections 3 and 4);

b) more restrictive vs. less restrictive category (lexical or grammatical) that is present in two (or more) contrasted languages (for example, kinship terms or colour terms across languages);

c) complementarity relations in concept or event lexicalisation (whereby the same or similar concept is expressed using different patterns available in two or more contrasted languages; for example path-in-the-verb vs. path-out-the-verb in motion expressions; see Slobin 2017 for the most recent overview).

These types of contrasts pose substantial difficulty in translation, especially when certain meanings are lexicalised or grammaticalized in one language but not the other. For example, the evidential marker mış in Turkish can refer to numerous different types of evidence for the source of the speaker's knowledge (e.g. retrospective, reflective, observable or third-hand/ hearsay; see Aikhenvald 2003; also Aikhenvald and Dixon 2003 for further details). Many other languages require that the main verb or the sentence as a whole is marked for evidentiality, or offer an optional set of affixes for indirect evidentiality. In English, this category is not grammaticalised, but there are a number of optional ways in which similar meaning of indirect evidence (though less precise or informative with regard to the source of information) can be expressed, such as Bobby seems/looks/would be tired. 
Translations from a language with grammaticalised evidentiality into English will have to involve decisions based on additional information available in individual situations (such as narrative context or knowledge about the semantics of the evidential). Very often the information from the evidential is simply not translated. For example, in literary translations from Turkish into English there is a tendency to omit the indications about the source of information even though the original text contains them (Sumeyra Tosun, pers. comm.). This may be understandable since a constant addition of modal verbs or constructions such as it seems / it appears etc. in order to render the approximate meaning of the Turkish suffix miş may be oppressive to the reader and not in line with the English narrative style. A similar difficulty was noticed in the translation from Turkish into Swedish (Csato 2009). Csato (2009) notes that while it is possible to render the evidential information from Turkish in Swedish, "no Swedish device can render the threefold ambiguity of the Turkish indirectives" because the inherent vagueness in the semantics of Turkish indirectives will generally be translated by Swedish forms with explicit meaning.

These contrasts are of particular relevance to certain communicative contexts, such as legal communication and evidence gathering. For instance, it may be important to state and translate, in a witness testimony, where the witness gets his or her knowledge from: personal experience or a third party source. Evidentials may make that information automatically available in Turkish, whether the evidence has been observed by the speaker or was available via a third party or hearsay, while that kind of information may not be readily or habitually available in English and may be challenging, or even impossible, to translate into English properly (see Givón 2009: 337). Applying language typology in different contexts of use probes for these kinds of difficulties, going beyond the statement that contrasts exist. It involves drawing conclusions with regard to what the contrasts mean, what impact they have. Contrasting languages without seeing how those contrasts are manifested in practice is only partially informative. That is why the practical usefulness of any language typology increases in value when the effects of the typological contrasts are tested and assessed in practical domains of use.

We now turn to two case study examples of the ways in which conceptualisation of events differs based on habitual ways of referring to those events in three languages, English, Serbian and Spanish, and how the relevant information about the events gets re-shaped in translation due to typological constraints that engender usage habits. 


\section{Morphosyntactic contrasts and their translations: Translating deictic meanings}

\subsection{Motion event typology}

One of the more recent language typologies was based on semantic differentiations in the lexicalisation of motion events. Motion events are ubiquitous in human life and this domain is therefore perfect for contrasting how different languages map onto it. Motion events typically have Figure, Path, Ground, and Manner components, and all languages of the world can be classified depending on where in the sentence these components are lexicalised. Len Talmy (1985) was the first who noticed that all languages opt for the expression of the central motion event component, path, either in the main verb or out of it.

We have to emphasise here that typological classifications, including this one, are based on typical / habitual / most frequent / unmarked lexicalisation patterns. Languages often have more than one lexicalisation alternative but it is what we consider the typical ones that form the basis for a typology. The examples from English, Spanish and Serbian below illustrate this central contrast.

(1a) Mary skipped into the house

$$
\begin{aligned}
& \text { (1b) Mary entró en la casa brincando. } \\
& \text { Maria enter.PST.3sg in the house skipping.G } \\
& \text { 'Mary entered the house skipping.' } \\
& \text { (1c) Meri je uskakutala u kuću. } \\
& \text { Mary be.cop into-skip.Pfv.3sG.F into house. } \\
& \text { 'Mary skipped into the house.' }
\end{aligned}
$$

Based on the examples (1a)-(1c) above, we can infer that English and Serbian pattern similarly, with the manner component expressed in the verb and path out of the verb, while Spanish expresses path in the verb and manner out of the verb. Both English and Serbian have the possibility to use the Spanish pattern as in (1b) but this possibility is not considered typical/habitual/the most frequent, which are the essential criteria for the typology (Talmy 1985). 
There is a difference between Serbian and English however. While there are no restrictions on the use of manner verbs in English, there are some restrictions in Serbian. Serbian has to employ the Spanish-like pattern of path in the verb rather than the English-like manner in the verb on certain specific occasions due to strict morphosyntactic restrictions where manner verbs cannot be used (as shown in Filipović 2007a). Serbian (as well as possibly some other languages from the Slavonic family) is best positioned on a typological cline between English and Spanish (see Filipović 2007a for a thorough discussion; see also Verkerk 2015 for a confirmation of the in-between position of Slavonic languages). For instance, the following translation of the English sentence would require a path verb in Serbian, just like the Spanish pattern, because an adequate prefixed manner verb in the required (imperfective) form (*išepavajući = out-limp.IPFV) cannot be derived due to morphological blocking:

(2a) John was limping out of the building when I saw him.

(2b) Juan estaba saliendo del edificio cojeando John be.IPFv exit.g out-of-the building limping cuando le ví. when him saw.PFV.1sG 'John was exiting the building limping when I saw him.'
(2c) Jovan je izlazio iz zgrade šepajući John be.cop exit.IPFv.3sG.m out building limping kada sam ga ugledao. when be.PRs.1sG him saw.PFV.1sG.m 'John was exiting the building limping when I saw him.'

We can say that this typology is best conceived of not as a strict dichotomy but rather as a continuum, as originally proposed in Filipović (1999). These insights bear relevance to both translation and second language acquisition and these contrasts between Serbian and English have been shown to cause difficulties for English learners of L2 Serbian (see Filipović and Vidaković 2012). Intratypological contrasts and their relevance for translation are discussed in more detail in Ibarretxe-Antuñano and Filipović (2013) and Filipović and Ibarretxe-Antuñano (2015). 
Luna Filipović: Language Contrasts in Translation

\subsection{The effects of typological language contrasts}

The differences between what is habitually expressed and what tends not be expressed in a language can have consequences for the quantity and quality of information in the original text vs. translation. If a sentential constituent is obligatory, such as the main verb, then the component it lexicalises is also more likely to feature in the motion expression. If a component is expressed in an optional constituent, such as manner in an adjunct in Spanish, then it may be possible not to include it in the motion expression with the same consistency. In fact, this is what research has shown (see Ibarretxe-Antuñano and Filipović (2013) and Filipović and Ibarretxe-Antuñano (2015) for a detailed overview). When this typology is applied in the context of translation, these important consequences are revealed. Slobin $(1996,1997,2003,2006)$ showed that the difference in lexicalisation patterns between Germanic (and also Slavonic and a number of other groups) and Romance (Spanish and other languages in this typological group) conditions the presence of manner information in the original English texts and their absence in Spanish translation. The English-like pattern favours manner information in the obligatory sentence constituent, the verb, while the Spanish-like pattern requires the use of path verbs and the information about manner is given in optional elements such as adjuncts (as illustrated in the previous section, example (1b)). Adding an optional manner adjunct should not be a problem. However, there are situations where doing so may impact the narrative in translation in a negative way. Consider the expression of continuous motion in English, such as (3a). Its translation into Spanish would require three verbs and either multiple gerunds to accompany each verb (3b) or the gerund put at the beginning of the sentence in order to convey the precise meaning that the Figure was running all the time $(3 \mathrm{c})$.

(3a) The man ran out of the post office, across the street and into the park.

(3b) El hombre salió de correos corriendo, cruzó la calle corriendo y entró en el parque corriendo.

'The man exited the post office running, crossed the street running and entered the park running.' 
(3c) Corriendo, el hombre salió de correos, cruzó la calle y entró en el parque.

'Running, the man exited the post office, crossed the street and entered the park.'

Both these options however go against the Spanish habitual language use and overburden the expression in that language. It is cumbersome to add a manner gerund after each path verb and also it is not typical to constantly start sentences with gerunds in Spanish, or any other language for that matter. This is why manner information is often left out in translation from English to Spanish (see Filipović 2008 for a discussion; see also Slobin 1996, 2003). Translation choices, especially in the literary context that Slobin and his associates studied, have to address the question of rhetorical style and translators have to make sure that their translated rendition does not sound unnatural in the target language, which would make it difficult to follow the narrative, or enjoy it. Consequently, the information about manner is often not present in Spanish translations of English texts even though it is given in the original language, as Slobin illustrates with the following example:

(4a) I ran out the kitchen door, past the animal pens, towards Jason's house.

(4b) Salí por la puerta de la cocina, pasé por los corrales y me dirigí a casa de Jasón.

'I exited through the kitchen door, passed by the animal pens and directed myself towards Jason's house.'

The official Spanish translation in (4b) contains three path verbs and no information on manner, while the English original has just a single manner verb. The information about the manner of motion is completely omitted in the translation in (4b), and this tendency is evident in over $50 \%$ of the cases in Slobin's extensive corpus of examined translations. Slobin explains that the imagery that is evoked by the original and the translation is completely different, and we can see why. The situation is much more dynamic in English than in Spanish as a result of a dynamic manner of motion verb being used. This dynamicity is absent in translation. Interestingly, Slobin also observed based on his study of translated novels, that the translation in the opposite direction, from Spanish into English, 
contains numerous additions of manner information even though none is present in the original (Slobin 1996).

It is important to highlight that effects of these typological contrasts can be found in texts other than literal - for example, legal. Filipović (2007b) analysed a large corpus of Spanish to English translations of police witness interviews. She noticed numerous spontaneous manner additions that are only present in the translated, English version but not given in the original Spanish. This is illustrated in the following example from Filipović (2007b):

(5a) Pero salió por la siete.

(5b) And then he ran onto the $7^{\text {th }}$ street. [official translation]

(5c) But he exited onto the $7^{\text {th }}$ street. [correct translation]

The sentence in (5a) is the original witness statement. Example (5b) is the official transcript translation and (5c) is the literal translation of the original. We can see that a different meaning and a different conceptualisation of the same event is caused by the difference between the information in the original and the translation. This is not a matter of style but rather of content. The use of bare path verbs is not the common English pattern, as it is in Spanish. This is why translators spontaneously use manner verbs when the target text is in English, more in line with the target language patterns. The two descriptions, the original and the translation, result in different conceptual representations, which may have practical consequences for subsequent events. For instance, a police officer may understand from the translation that the suspect was running based on the translated statement of the witness, while the original statement did not actually mention running. Further inferences can be made as to how far the suspect may have gone, which differs depending on whether he was running or not. These practical implications for the professional context of police interviews with an interpreter need to be emphasised and incorporated in the training of both officers and interpreters.

Another practical context where the consequences of language contrasts can have an impact is jury judgment. Ibarretxe-Antuñano and Filipović (2013) report on a translation and mock jury judgment study, driven by the applied typology approach advocated here. The authors discuss the typological contrasts between languages that lead to contrasts between judgments made in the two languages. For instance, language 
can impact our judgment of the severity of violence and estimates of its outcomes depending on how semantically rich the verbs used in the descriptions are. Specifically, in the study by Ibarretxe-Antuñano and Filipović (2013), manner-rich English translations elicited higher ratings on the severity of violence and the consequences of the violence than the manner-scarce original descriptions in Spanish.

\subsection{Focus on deixis}

When we apply the typology in the context of translation from English into Serbian we notice that there are some contrasts that are not captured by the key typological parameter of path in the verb / path out of the verb. Serbian makes extensive use of deictically prefixed manner verbs, such as: otrčati ("from the speaker/scene-run") and dotrčati ("to-the speaker/scene-run"). The OD-/DO-prefixed verbs are the least restricted ones morphosyntactically, because they can be combined with any other preposition without any restrictions and can accumulate numerous prepositions if necessary to express a multi-part path of motion (see examples (6b) and (6c)). These verbs are the most frequent in dictionaries (Filipović 2007a) and they also have higher corpus frequencies than verbs prefixed otherwise. The advantage of using a manner verb in translation is illustrated below: ${ }^{2}$

(6a) He staggered out of the kitchen, through the corridor and into the bathroom.

(6b) Oteturao se iz kuhinje, from-speaker/scene-stagger.PST.3sG.M REFL out kitchen kroz hodnik, u kupatilo. through hall into bathroom 'He staggered out of the kitchen, through the hall and into the bathroom.'

2 It is important to note here that manner verbs prefixed with the deictic prefixes OD- and DO-, in spite of their less restricted use, cannot be used in the situations such as those expressed in the example (2c) when the moment of change of location is communicated and an imperfective path verb must be used instead (see Filipović 2007a for details). 
Luna Filipović: Language Contrasts in Translation

(6c) Doteturao se iz kuhinje, to-speaker/scene-stagger.PST.3SG.M REFL out kitchen kroz hodnik, u kupatilo.

through hall into bathroom

'He staggered out of the kitchen, through the hall and into the bathroom.'

(6d) Isteturao

\begin{tabular}{llll} 
se & iz & \multicolumn{2}{c}{ kuhinje, } \\
REFL & out & \multicolumn{2}{c}{ kitchen } \\
\\
\multicolumn{2}{c}{ Se } & kroz & hodnik \\
REFL & through & hall \\
& se & u & kupatilo. \\
3SG.M & REFL & into & bathroom
\end{tabular}

out-stagger.PST.3sG.M

proteturao

through-stagger.PST.3sG.M

i uteturao se $u$ kupatilo.

and into-stagger. PST.3SG.M REFL into bathroom

'He staggered out of the kitchen, through the hall and into the bathroom.'

(6e) Teturajući se, izašao je iz kuhinje, staggering REFL exit.PST.3sG.M COP out kitchen prošao kroz hodnik

pass.PsT.3sG.m through hall

i ušao u unatilo.

and enter.pst.3sg.m into bathroom

'Staggering, he exited the kitchen, went through the hall and entered the bathroom.'

(6f) Izašao je iz kuhinje teturajući se, exit.PST.3SG.M COP out kitchen staggering REFL prošao kroz hodnik teturajući se pass.PST.3sG.m through hall staggering REFL i ušao u kupatilo teturajući se. and enter.PST.3sG.M into bathroom staggering REFL 'He exited the kitchen staggering, passed through the hall staggering and entered the bathroom staggering.'

(6g) *Isteturao se iz kuhinje kroz hodnik out-stagger.PST.3sG.m REFL out kitchen through hall u kupatilo.

into bathroom.

'He staggered out of the kitchen, through the hall into the bathroom.' 
We can see that of all the possible translations from English into Serbian the options with OD-/DO-manner verbs (6b and 6c) are closer to the English original and they also package the intended meaning from the original more efficiently than the others. Other translation options range from infelicitous to ungrammatical. If OD-/DO- verbs are not used, then multiple manner verbs prefixed with a different prefix (instead of a single OD-/DO- verb) would be needed because none of these verbs on its own can be combined with all the different prepositions that are necessary for the whole path of motion to be expressed (see 6d). Options (6e) and (6f) are comparable to the options in Spanish in (3b) and (3c) and suffer from the same problems: (6e) displaces the manner information from the manner verb into a gerund that is placed at the beginning of the sentence, putting more emphasis on this component than originally intended. If this translation option were chosen often, which it would have to be considering the frequency with which manner is expressed in English, the narrative would sound awkward, to say the least. In the case of (6f), we see that gerund repetition with each verb is also not a felicitous option: it overburdens the sentence structure and the whole narrative (see also (3c) for the same situation in the Spanish translation of a similar example above). Finally, (6g) shows that a single manner verb prefixed by a different prefix (IZ- 'out of') and not the deictic OD-/DO- cannot successfully be used to capture both the manner and the multiple paths of motion. A verb prefixed by IZ- cannot accumulate all the necessary path prepositions in order to lexicalise the whole path (see Filipović 2007a for details on this phenomenon called combinatory potential).

Overall, the use of three verbs instead of one to convey the same or very similar meaning makes such translation options less efficient and in general speakers want to be efficient unless they have a reason for verbosity (see Filipović 2014 on bilingual efficiency). The economical packaging of information is one of the big advantages of the English lexicalisation patterns in general. It has been noted that Spanish translations of English texts are always longer, in both literary (Slobin 1996) and legal contexts (Berk-Seligson 1990). Thus, the choice above is really between (6b) and (6c), since multiple manner verbs prefixed with different prefixes for each portion of the path and also multiple path verbs are significantly less optimal. The key point of relevance here is the fact that the position of the speaker or witness would be inferable in the translation in Serbian but not in the English original. In (6c) the movement happened away 
from the speaker (the speaker/scene focus was out of the kitchen) and in (6b) it happened towards the speaker (the speaker/scene focus was in the kitchen). There is a particular dearth of manner verbs prefixed by up and down prefixes in Serbian (Filipović 2007a) and OD-/DO-deictic verbs are used in the absence of deictic-neutral manner verbs. Motion along the vertical scale is much less often analysed, and it should receive more attention because it can reveal numerous linguistic contrasts that are relevant for the relationship between language and conceptualisation as well as for translation (see in particular Bosque 2015 for an insightful and detailed discussion of lexicalisation of vertical motion in Spanish). In Serbian, there are no "up-stagger" or "down-stagger" prefixed verbs, and the deictic "oteturao se uz stepenice" (from-the speaker/scene-stagger up the stairs) or "doteturao se uz stepenice" (to-the-speaker/scene- stagger up the stairs) would have to be used instead for verbalisation of such motion events (ditto for most other manner verbs in vertical motion scenes in Serbian; see Filipović 2007a; Filipović and Hijazo-Gascón (in press)).

Why is deixis relevant for lexicalisation of motion events and for translation? Deixis is the process of referring to an object or an event that is positioned or is occurring at a certain point with relation to the speaker or hearer in a communicative situation. Therefore, it is not an inherent part of events as such, as the other components defined by Talmy (1985) are. However, the importance of deictic viewpoint cannot be underestimated because it is an important indication of the position of the speaker who is describing the event. Both Spanish and English have the possibility to express deixis by using the verbs come and go (e.g. by saying He came up running or He went up running). However, this is not the most frequent or preferred pattern for motion lexicalisation in these two languages and if constantly used, such use will be marked. In Serbian, prefixed manner verbs are a habitual pattern and the deictic information from the OD-/DOprefixes is often an addition in translation from English. Conversely, the deictic information conveyed by the OD-/DO- manner verbs in Serbian is often omitted in translations from Serbian to English (Filipović 1999, 2007a). Furthermore, these subtle yet important linguistic features pose substantial practical difficulty in an L2 acquisition context (see Section 5 for further details). Filipović and Hijazo-Gascón (in press) point out that linguistic elements for the expression of deixis similar to the ones discussed here are used in Japanese (Matsumoto, Akita and Takahashi 2017) and German (Bamberg 1994). These devices present a complex difficulty for 
language learners (see Yoshinari 2015 for learners of Japanese and ListeLamas 2015 for learners of German). Knowing where the language we are learning or translating from and into belongs typologically is helpful because it can add focus and alert us about the potential ease or difficulty that we will encounter in our linguistic activities. Teaching and training plans can then be made accordingly, depending on different typological parameters (see Filipović 2017a, 2017b).

The consequence of importance here is also that the description of an event in the original language and the translation may lead to a difference in the conceptual representation of these events. For example, it may be important to understand, in a witness testimony, where the witness was located when observing the event that he or she is describing. The positioning of the witness is relevant for the ascertaining of the fact that the witness was indeed capable of seeing the relevant aspects of the witnessed scene (e.g. conditioned by a viewing angle, distance, etc). The role of applied language typology is to document these effects that go beyond the mere language contrasts themselves and this can have further consequences for our understanding of witnessed and described events, in the original and in translation. This is why applying insights about typological similarities and differences across different contexts of use is fundamental for a proper understanding of their effects and their potential practical impact.

\section{Semantic contrasts and their translations: The case of intentional vs. non-intentional causation}

Another typological language contrast that illustrates the importance of studying its consequences in concrete practical contexts in context is causation, or more precisely, the typological tendency to specify whether causation was intentional or not. In this domain, Slavonic and Romance languages pattern similarly, while English differs from both. Namely, Serbian and Spanish have different constructions that are used to distinguish between two different types of events, intentional (7a and 8a) vs. non intentional (7b and 8b), as illustrated below:

$\begin{array}{llll}\text { (7a) } & \text { Razbio } & \text { sam } & \text { čašu. } \\ \text { break.PFv.1sG.m } & \text { cop } & \text { glass.ACC.F } \\ \text { 'I broke a glass.' } & & \end{array}$


Luna Filipović: Language Contrasts in Translation

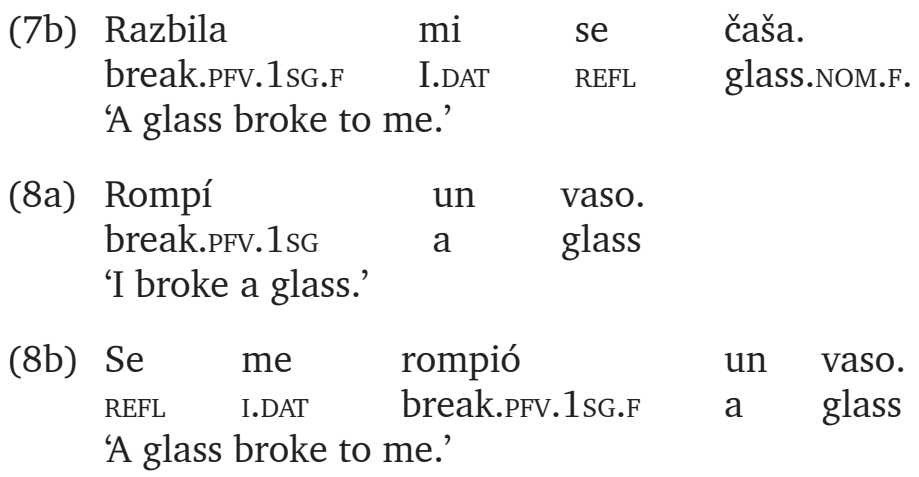

English, on the other hand, normally uses the same construction for both event types, as in:

(9) I broke a glass.

There is also the possibility to use the inchoative constructions such as The glass broke but this construction does not express all the necessary event participants, such as the involuntary agent that was involved in the unintentional breaking, so it is not quite the same as the expressions in Serbian and Spanish above. Crucially, unlike Serbian and Spanish, the English inchoative construction is not used only for accidental, nonintentional events. It is rather unspecified for native speakers of English since it can be used to express actions that may have happened either with or without intent (e.g. She pushed the glass off the table and it broke [intentionally or not?]). Moreover, recent research (Filipović 2016) has shown that the inchoative construction is not consistently used by native speakers of English to discriminate intentional from non-intentional acts but is rather used interchangeably as a description of both intentional video stimuli, e.g. The girl pushed the doll and it fell off the bed, and nonintentional video depictions of actions, e.g. The woman knocked the bottle off the table and it fell down.

There are ways in which English can express this distinction of presence vs. absence of intentionality, for example by adding an adverbial or adverbial phrase, such as She broke the glass inadvertently/accidentally/ by accident. However, this is not consistently and habitually done for each event in English by native speakers, it is an optional dimension.

The constructions in (7b) and (8b) in Serbian and Spanish respectively are the affective dative constructions. We can see how the original sentence 
in English can legitimately receive two different translations in Spanish and Serbian, one which indicates that the action described was intentional and one that specifies that the action was unintentional. In the following example, different verbs are also needed for each of the two constructions in Serbian and Spanish, unlike the examples in (7) and (8) above, where the same verb with different morphological marking could be used:

(10a) The man dropped the pencil on the floor.

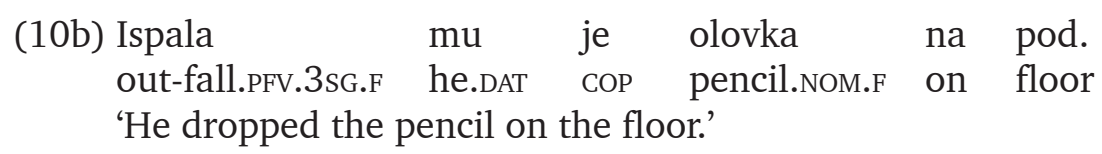

(10c) Bacio je olovku na pod. throw.PFV.3sG.M COP pencil.ACC.F on floor 'He threw the pencil on the floor.'

$\begin{array}{lllll}\text { (10d) } \mathrm{Se} \quad \text { le } & \text { cayó } & \text { el lápiz al suelo. } \\ \text { REFL he.DAT fall.PFv.3sG the pencil } & \text { on-the } & \text { floor } \\ \text { 'He/She dropped the pencil on the floor.' } & & \end{array}$
(10e) Tiró
el
lápiz
al
suelo.
throw.PFv.3sG the
pencil
on-the floor
'He/She threw the pencil on the floor.'

It should not be up to the interpreter to make the decision of whether the action was intentional or not, and this is precisely what happened in the forensic linguistic context of a witness testimony discussed in the next section. It is easy to see how translation can sway interpretation towards intentional meaning in the target text while unintentional meaning is given in the original. Events can be conceptualised in a completely opposing fashion as a result. For instance, Filipović (2007b) has shown that a suspect in a police interview was repeating "se me cayóen las escaleras" (= "me it happened that she fell on the stairs') when she was explaining how the victim she was carrying down the stairs ended up sustaining her (sadly, fatal) injuries. This was translated as the underspecified "I dropped her on the stairs" and taken to be a confession of an intentional act, which in the state of California, where the research was undertaken, carries the most severe punishment. 
Thus, we can see how the consequences of such conceptualisation disparity between the original and the translation can be more serious than a mere difference of style. Here, it is rather a matter of difference in content, and an important matter as well. Namely, if proclamation of innocence can be interpreted as admission of guilt as a result of translation, we need to be alert and vigilant when translating. It is important to emphasise that it is not bad translation that we are highlighting here but rather the typological differences between languages that create language-specific narrative habits to constantly mention or not mention certain information about events or to consistently make or not make certain distinctions. These contrastive habits in lexicalisation patterns and typological preferences can also have a further effect that goes beyond linguistic differences per se.

Psycholinguistic research has detected an impact on witness memory based on the language in which the witnessed events are described. Crucially for us at present, it seems that if the speaker's L1 has the benefit of encoding certain distinctions like those in the domain of intentionality we discussed, they tend to reap that benefit even when speaking an L2 that does not grammaticalise or lexicalise the relevant distinctions. These speakers tend to find a way to translate the relevant meanings from their L1 into their L2. Language-specific effects on memory for intentional vs. non-intentional causation were first detected by Filipović (2013), in a study which involved monolingual speakers of English and Spanish and which demonstrated that Spanish speakers always expressed the differences in intentionality while English speakers did not. The memory for intentionality vs. non-intentionality was better in Spanish speakers as a result. These cross-linguistic differences in the domain of intentionality have also been captured in the context of second language acquisition (Filipović 2016). Namely, L1 English learners of L2 Spanish did not regularly and explicitly distinguish between intentional and non-intentional actions in L2 Spanish and their memory for causation was worse than those of L1 Spanish learners of L2 English, who always explicitly distinguished intentional from nonintentional events even in L2 English, where the relevant distinctions are not lexicalised. The L1 Spanish/L2 English speakers found some meaning equivalents, which are practically translation equivalents for intentional and non-intentional meanings lexicalised in their L1, and which convey the meaning of their L1 category distinctions in their L2 English. This was achieved by a consistent introduction of adverbs such as accidentally if the action was non-intentional and on purpose if it was intentional. Another 
strategy was the use of inchoative constructions such as The glass fell exclusively for non-intentional events. In contrast, there was no consistent intentionality differentiation by L1 English/L2 Spanish speakers. When they spoke L2 Spanish they used intentional and non-intentional constructions interchangeably, without paying attention to the intentionality of the stimuli. English speakers overall tend to use the SVO constructions such as (10a) in their language as underspecified and applicable in both intentional and non-intentional situations. Intuitions about intentionality may vary with individual verbs. For example, some verbs like drop may be understood to refer primarily to non-intentional events, while some others like push may imply intentionality as a default. In any case, it is clearly not a specified grammatical, lexical or usage feature of English to consistently specify intentionality as Serbian and Spanish apparently do.

\section{Conclusions and directions for future research}

We can conclude that the explicit insights made available within the applied typology framework can lead to a better understanding of what can go wrong in translation and cross-linguistic communication and the consequences of unresolved typological conflicts between languages. Sometimes the costs of mistranslation or miscommunication are too high to ignore, and thus raising awareness about them, preventing them and successfully resolving them as soon as they arise should be an important part of the training of translators and language teachers and should be integrated into teaching materials for learners. More efficient and better quality of learning and use of languages would be the result, as well as avoidance of inequality in access to justice, medical, educational and other social services. In this way, the pedagogical ideals of contrastive linguistics and the cognitive importance of language contrasts can be united towards an important practical goal of better communication, which benefits individuals and societies.

Linguistic theory also stands to benefit from research in this vein. Empirical insights from applied typology research can feed back crucial information that can contribute to better theoretical formulations, especially regarding the extent to which language and cognition interact and influence each other.

The crucial role of translation in applied language typology research, and in any kind of investigation involving contrasting of languages, 
is evident in our discussion in this paper. Explicit teaching of language contrasts and their cognitive and practical consequences in translation is paramount not only for professional interpreters and translators but also other professionals who communicate multilingually using translation and interpretation services.

Further research along these lines should consider the many diverse aspects of lexicons and grammars across languages still not contrasted from an applied linguistic viewpoint. Insights from different language typologies can also be applied together so that the interactions between morphological, syntactic and semantic features used for different typological classifications can be properly captured. A typological approach helps us make our claims more generalisable, though we have to bear in mind that intratypological variation means that some subtle differences may still exist among the languages that are classified into the same group under a typology. The study of language contrasts in translation exemplified here hopefully paves the way for future discoveries about the similarities and differences among different languages in different contexts of use as well as about the effects of language-driven conceptual representation.

\section{References}

Aikhenvald, A. Y. (2004). Evidentiality. New York: Oxford University Press.

Aikhenvald, A. Y. and R. M. W. Dixon (eds) (2003). Studies in Evidentiality [Typological Studies in Language, Vol. 54]. Amsterdam: John Benjamins.

Athanasopoulos, P. (2016). Cognitive consequences of multi-competence. In: V. Cook and L. Wei (eds), The Cambridge Handbook of Linguistic Multi-competence. Cambridge: Cambridge University Press, 355-375.

Bamberg, M. (1994). Development of linguistic forms: German. In: R. A. Berman and D. I. Slobin (eds), Relating Events in Narrative: A Crosslinguistic Developmental Study, Hillsdale, NJ: Lawrence Erlbaum Associates, 189-238.

Berk-Seligson, S. (1990). The Bilingual Courtroom: Court Interpreters in the Judicial Process. Chicago: University of Chicago Press.

Bosque, I. (2015). Inner and outer prepositions with Spanish verbs of vertical movement. In: E. Barrajón López, J. Cifuentes-Honrubia and 
S. Rodríguez Rosique (eds), Verb Classes and Aspect, Amsterdam: John Benjamins, 77-97.

Bugarski, R. (1991). Contrastive analysis of terminology and the terminology of contrastive analysis. In: V. Ivir and D. Kalogjera (eds), Languages in Contact and Conflict. Berlin/New York: Mouton de Gruyter, 73-92.

Bugarski, R. (1996[1969]). Predlozi over, under, above, below $i$ beneath u savremenom engleskom jeziku [The Prepositions over, under, above, below and beneath in Contemporary English] Belgrade: Čigoja.

Csató, É. Á. (2009). Rendering Evidential Meanings in Turkish and Swedish. In: É. Á. Csató, G. Ims, J. Parslow, F. Thiesen and E. Türker (eds), Turcological Letters to Bernt Brendemoen [The Institute for Comparative Research in Human Culture Oslo Serie B: Skrifter 132], Oslo: Novus, 77-86.

Filipović, L. (1999). Language-specific expression of motion and its use in narrative texts. MPhil Dissertation, University of Cambridge.

Filipović, L. (2007a). Talking about Motion: A Crosslinguistic Investigation of Lexicalization Patterns. Amsterdam: John Benjamins.

Filipović, L. (2007b). Language as a witness: Insights from cognitive linguistics. Speech, Language and the Law 14(2), 245-267.

Filipović, L. (2008).Typology in action: Applying insights from typological contrasts. International Journal of Applied Linguistics 18 (1), 42-61.

Filipović, L. (2013). Constructing causation in language and memory: Implications for access to justice in multilingual interactions. International Journal of Speech, Language and the Law 20 (1), 1-19.

Filipović, L. (2014). Efficiency of the bilingual mind: Clues from processing, memory and second language acquisition studies. In: L. Filipović and M. Pütz (eds), Multilingual Cognition and Language Use: Processing and Typological Perspectives [Human Cognitive Processing Series 44]. Amsterdam: John Benjamins, 205-227.

Filipović, L. (2016). Speaking in L2 but thinking in L1: Language-specific effects on memory for causation events in English and Spanish. International Journal of Bilingualism. https://doi.org/10.1177/13670 06916661636

Filipović, L (2017a). Applied Language Typology: Applying typological insights in practice. Languages in Contrast 17:2, 255-278.

Filipović, L. (2017b). Applying language typology: Practical applications of research on typological contrasts between languages. In: I. IbarretxeAntuñano (ed), Motion and Space across Languages and Applications 
Luna Filipović: Language Contrasts in Translation

[Human Cognitive Processing Series 44]. Amsterdam. John Benjamins, 399-418.

Filipović L. and I. Vidaković (2010). Typology in the L2 classroom: Second language acquisition from a typological perspective. In: M. Pütz and L. Sicola (eds), Inside the Learner's Mind: Cognitive Processing in Second Language Acquisition, Amsterdam: John Benjamins, 269-291.

Filipović, L. and K. Jaszczolt (eds) (2012a). Space and Time across Languages and Cultures Vol 1: Linguistics Diversity [Human Cognitive Processing Series 36]. Amsterdam: John Benjamins.

Filipović, L. and K. Jaszczolt (eds) (2012b). Space and Time across Languages and Cultures Vol 2: Language, Culture and Cognition [Human Cognitive Processing Series 37]. Amsterdam: John Benjamins.

Filipović, L. and J. A. Hawkins (2013). Multiple factors in second language acquisition: The CASP model. Linguistics 51 (1), 145-176.

Filipović, L. and I. Ibarretxe-Antuñano (2015). Motion. In: E. Dąbrowska and D. Divjak (eds), Handbook of Cognitive Linguistics (Handbooks of Linguistics and Communication Science 39). Berlin: Mouton de Gruyter, 527-545.

Filipović, L.and A. Hijazo-Gascón (in press) Interpreting meaning in police interviews: Applied Language Typology in a forensic linguistics context. Vigo International Journal of Applied Linguistics VIAL.

Givón, T. (2009). Mind, Code and Context: Essays in Pragmatics. New York: Psychology Press.

Greenberg, J. H. (1963). Some universals of grammar with particular reference to order of meaningful elements. In: J. H. Greenberg (ed), Universals of Language, Cambridge, MA: MIT Press, 73-113.

Greenberg, J. H. (1966). Language Universals with Special Reference to Feature Hierarchies. The Hague: Mouton.

Halverson, S. (2014). Reorienting translation studies: Cognitive approaches and the centrality of the translator. In: J. House (ed), Translation: A Multidisiciplinary Approach, London: Palgrave Macmillan, 116-139.

Hawkins, J. A. (1983). Word Order Universals. New York: Academic Press.

Hawkins, J. A. (1986). The Comparative Typology of English and German: Unifying the Contrasts. London and Sydney: Croom Helm.

Hawkins, J. A. (2014). Cross-linguistic Variation and Efficiency. Oxford: Oxford University Press.

Hawkins, E. (1984). Awareness of Language: An Introduction. Cambridge: Cambridge University Press. 
James, C. (1990[1980]). Contrastive Analysis. Harlow, Essex: Longman.

House, J. (2013). Towards a new linguistic-cognitive orientation in translation studies. Target 25 (1), 46-60.

Ibarretxe-Antuñano, I. (ed) (2017). Motion and Space across Languages and Applications [Human Cognitive Processing Series 44]. Amsterdam: John Benjamins.

Ibarretxe-Antuñano, I. and L. Filipović (2013). Lexicalization patterns and translation. In: A. Rojo and I. Ibarretxe-Antuñano, I. (eds), Cognitive Linguistics and Translation. Berlin: Mouton de Gruyter, 253-284.

Kellerman, E. (1983). Now you see it, now you don't. In: S. Gass and L. Selinker (eds), Language Transfer in Language Learning, Rowley, MA: Newbury House, 112-134.

Lado, R. (1957). Linguistics across Cultures: Applied Linguistics for Language Teachers. Ann Arbor, MI: University of Michigan.

Lai, T., G. G. Rodriguez and B. Narasimhan (2014). Thinking-for-speaking in early and late bilinguals. Bilingualism: Language and Cognition, 17(1), 139-152.

Liste-Lamas, E. (2015). German directional adverbs with hin- and her-: A preliminary study on their acquisition by L1 speakers of Spanish. In: I. Ibarretxe-Antuñano and A. Hijazo-Gascón (eds), New Horizons in the Study of Motion: Bringing Together Applied and Theoretical Perspectives, Newcastle upon Tyne: Cambridge Scholars Publishing, 10-31.

Matsumoto, Y., K. Akita and K. Takahashi (2017). The functional nature of deictic verbs and the coding patterns of Deixis: An experimental study in English, Japanese and Thai. In: I. Ibarretxe-Antuñano (ed), Motion and Space across Languages. Theory and Applications, Amsterdam: John Benjamins, 95-122.

Odlin, T. (1989). Language Transfer. New York: Cambridge University Press.

Pavlenko, A. (2014). The Bilingual Mind. Cambridge: Cambridge University press.

Rojo, A. and P. Cifuentes Ferez (2017). On the reception of translations: Exploring the impact of typological differenceson legal contexts. In: I. Ibarretxe-Antuñano, I. (Ed.) Motion and Space across Languages and Applications [Human Cognitive Processing Series 44]. Amsterdam. John Benjamins, 367-398.

Rojo, A. and I. Ibarretxe-Antuñano (eds) (2013). Cognitive Linguistics and Translation. Berlin: Mouton de Gruyter. 
Slobin, D. I. (1996). Two ways to travel: verbs of motion in English and Spanish. In: M. Shibatani and S. A. Thompson (eds), Grammatical Constructions: Their Form and Meaning, Oxford: Clarendon Press, 195-220.

Slobin, D. I. (1997). Mind, code, and text. In: J. Bybee, J. Haiman and S. Thompson (eds), Essays on Language Function and Language Type, Amsterdam: John Benjamins, 437-467.

Slobin, D. I. (2003). Language and thought online: Cognitive consequences of linguistic relativity. In: D. Gentner and S. Goldin-Meadow (eds), Language in Mind, Cambridge, MA: MIT Press, 157-191.

Slobin, D. I. (2004). The many ways to search for a frog: Linguistic typology and the expression of motion events. In: S. Strömqvist and L. Verhoeven (eds), Relating Events in Narrative: Typological and Contextual Perspectives, Mahwah, NJ: Lawrence Erlbaum, 219-257.

Slobin, D. I. (2006). What makes manner of motion salient? Explorations in linguistic typology, discourse, and cognition. In: M. Hickmann and S. Robert (eds), Space in Languages: Linguistic Systems and Cognitive Categories, Amsterdam: John Benjamins, 59-81.

Slobin, D. I. (2017) Typologies and language use. In: I. Ibarretxe-Antuñano, I. (ed), Motion and Space across Languages and Applications [Human Cognitive Processing Series 44], Amsterdam. John Benjamins, 419-445.

Talmy, L. (1985). Lexicalization patterns: semantic structure in lexical form. In: T. Shopen (ed), Language Typology and Syntactic Description, Vol. 3: Grammatical Categories and the Lexicon, Cambridge: Cambridge University Press, 36-149.

Ungerer, F. and H.-J. Schmidt (1996). An Introduction to Cognitive Linguistics. London: Longman.

Verkerk, A. (2015). Where do all the motion verbs come from? The speed of development of manner verbs and path verbs in Indo-European. Diachronica, 32, 69-104.

Yoshinari, Y. (2015). Describing motion events in Japanese L2 acquisition: How to express deictic information. In: I. Ibarretxe-Antuñano and A. Hijazo-Gascón (eds), New Horizons in the Study of Motion: Bringing Together Applied and Theoretical Perspectives. Newcastle upon Tyne: Cambridge Scholars Publishing, 32-63.

Received: 23 September 2017

Accepted for publication: 31 January 2018 
Луна Филиповић

\author{
ЈЕЗИЧКИ КОНТРАСТИ У ПРЕВОДУ: \\ КОГНИТИВНЕ И ПРАКТИЧНЕ ПОСЛЕДИЦЕ
}

\title{
Сажетак
}

Могу ли језичке разлике довести до различитих концептуализација догађаја? У овом чланку ћемо видети да могу, у контексту превода и у неким другим контекстима употребе језика, као што су меморија и доношење одлука. Фокус је првенствено на превођењу и његовој повезаности са другим подручјима истраживања, као што је контрастивна и когнитивна лингвистика. Овде илуструјемо како све ове области могу бити међусобно корисне. Теоријска основа за анализу дата је у оквиру применене типологије језика, која представља нову платформу за испитивање језичких контраста у различитим практичним контекстима вишејезичне употребе, као што су превођење, учење језика и правна комуникација (полицијски интервјуи и сакупљање доказа). Анализирамо два когнитивна домена, кретање и узрочност, и начине њихове лексикализације на различитим језицима, укључујући контрастне карактеристике на морфолошком, синтаксичком и семантичком нивоу. Закључак је да холистички приступ анализи који који укључује когнитивне и практичне последице језичких контраста представља пут напред за контрастивно примењено језичко истраживање и студије превођења.

Кључне речи: кретање, узрочност, интенционалност, деикса, превођење 